\title{
PENGARUH BUDAYA ORGANISASI TERHADAP PENGELOLAAN RASTRA DI DESA BULUCENRANA KECAMATAN PITU RIAWA KABUPATEN SIDENRENG RAPPANG
}

\author{
1)EImayanti, 2)Hariyanti Hamid, 3)Monalisa Ibrahim \\ Fakultas IImu Sosial dan IImu Politik Universitas Muhammadiyah Sidenreng Rappang \\ elmayanti483@gmail.com
}

\begin{abstract}
Abstrak
Penelitian meberikan tujuan untuk memahami pengaruh budaya organisasi terhadap pengelolaan rastra di Desa Bulucenrana Kecamatan Pitu Riawa Kabupaten Sidenreng Rappang dan memahami faktor-faktor yang memengaruhi budaya organisasi di Desa Bulucenrana Kecamatan Pitu Riawa Kabupaten Sidenreng Rappang. Populasi penelitian ini adalah sebanyak 119 orang. Sampel sebanyak 54 orang. Teknik penarikan sampel yang difungsikan adalahPurpossive Sampling. Tipe penelitian ini adalah deskriptif kuantitatif. Teknik pengumpulan data yang difungsikan adalah observasi, wawancara, kuesioner dan studi pustaka. Teknik analisis data yang difungsikan adalah statistik deskriptif dan dengan belaan aplikasi SPSS versi 21. Buatan penelitian menunjukkan bahwa Pengaruh Budaya Organisasi di Desa Bulucenrana dengan persentase $59.58 \%$ berada pada kategori kurang baik. Pengelolaan Rastra di Desa Bulucenrana dengan persentase $55.66 \%$ berada pada kategori kurang baik. Berdasarkan nilai $t$ hitung $>t$ tabel atau $2.750>2.006$, maka HO ditolak artinya Pengaruh Budaya Organisasi berpengaruh signifikan terhadap Pengelolaan Beras Sejahtera di Desa Bulucenrana Kecamatan Pitu Riawa Kabupaten Sidenreng Rappang persentase sumbangan pengaruh 57.1\%. Faktor-faktor yang Memengaruhi Budaya Organisasi: 1. Faktor sejarah organisasi 58\%, 2. Faktor budaya $58,4 \%$ dan 3 . Faktor bahasa $54,4 \%$. Berdasarkan dari uraian tersebut di atas, bahwamampu disimpulkan bahwa faktorfaktor yang memengaruhi BudayaOrganisasi di Desa Bulucenrana dengan persentase $56.66 \%$ berada pada kategori kurang baik.
\end{abstract}

Kata kunci : Pengaruh Budaya Organisasi dan Pengelolaan Rastra

\begin{abstract}
This research provides a purpose to understand culture on prosperous rice management in Bulucenrana Village, Pitu Riawa District, Sidenreng Rappang Regency and to determine the factors that influence organizational culture in Bulucenrana Village, Pitu Riawa District, Sidenreng Rappang Regency. The population of this research was 119 people. A sample of 54 people. The sampling technique used was purposive sampling. This type of research is descriptive quantitative. The data collection techniques used were observation, interview, questionnaire and literature study. The data analysis technique used was descriptive statistics and with the help of the SPSS version 21 application. The results showed that the influence of organizational culture in Bulucenrana village with a percentage of $59.58 \%$ was in the unfavorable category. Rastra management in Bulucenrana Village with a percentage of $55.66 \%$ is in the poor category. Based on the value of $t$ count $>t$ table or 2.750> 2.006, then $\mathrm{HO}$ is rejected, meaning that the influence of organizational culture has a significant effect on the management of prosperous rice in Bulucenrana Village, Pitu Riawa District, Sidenreng Rappang Regency with a contribution percentage of $57.1 \%$. Factors Affecting Organizational Culture: 1. Organizational history factors $58 \%$, 2. Cultural factors $58.4 \%$ and 3. Language factors $54.4 \%$. Based on the explanation above, it can be concluded that factors affecting the Organizational Culture in Bulucenrana Village with a percentage of $56.66 \%$ are in the unfavorable category.
\end{abstract}

Keywords: The Effect of Organizational Culture and Prosperous Rice Management

Volume 8 | Nomor 3 | Edisi Desember $2020 \mid$ JIA 


\section{A. PENDAHULUAN}

Berdasarkan Undang-Undang Republik Indonesia Nomor 18 Tahun 2012 tentang pangan adalahpemenuhan dan kebutuhan dasar manusia yang paling utamaadalah bagian dari hak asasi manusia yang dijamin di dalam Undang-Undang Dasar Negara Republik Indonesia Tahun 1945 sebagai anggota dasar untuk menjadikan sumber daya manusia yang berkualitas, yakni tercantum dalam BAB IV pasal 13adalahpemerintah berkewajiban mengelola harga pangan pokok dan stabilitas pasokan, melaksanakandistribusi pangan pokok dan cadangan pangan pokok pemerintah untuk menjadikan kecukupan pangan pokok yang bergizi dan aman bagi masyarakat.

Sebuah organisasi dibentuk untuk menyelesaiakn suatu tujuan.Tujuan organisasi dapat bersifatpeningkatan kualitas produk atau jasa, perbaikan pelayanan, peningkatan kinerja organisasi dan peningkatan daya saing.Tujuan tersebut memperoleh keberhasilan, dalam mengoperasikan unit-unit kerja sangat dipengaruhi oleh kinerja pegawai yang ada di dalam sebuah organisasi.Kinerja yang bermakna adalah kinerja yang baik. Indikator dari kinerja tersebut semakin bermakna, maka suatu kinerja semakin tinggi. Hanya kinerja yang tinggi dapat melakukankeampuhan dan kemampuan saing suatu organisasi cara jangka panjang.

Belaan kemasyarakatan beras sejahteraberas fisik diberikan dalam gambaran dengan kualitas dan kuantitas sesuai dengan yang telah ditetapkan oleh peraturan yang berlaku.Budaya organisasi memiliki hubungandengan kinerja yang erat, budaya organisasi yang membelauntukdapat mengarahkan atau memandu perilaku kerja baikakhirnya anggota organisasi mampu mengantarkan organisasi secara kelegkapan dalam menyelesaiakn ttujuannya. Dasarnya seluruh organisasi mempunyai budaya,tidak semua budaya organisasi sama kuatnya dalam mempengaruhi kelakuan dan kegiatan para pegawai, semakin besar keterkaitan mereka pada nilai-nilai dan semakin tinggi tingkat Pengurusan para pgawai terhadap nilai-nilai poko organisasi tersebut, maka semakin kuat budaya organisasinya

Keberbuatanan rastra diukur berlandaskantingkat pencapaian ada enam indicator tepat 6 Tadalah tepat jumlah, tepat sasaran, tepat waktu, tepat harga, tepat kualitas dan tepat tata laksana. Pedoman umum (pedum) pembagian rastra adalahpengelola arahan rastra untuk memenuhienam $\mathrm{T}, \quad$ yang menangkapperorganisasian dan pengelolaan, panganggaran dan perencanaan, pelaporan dan mekanisme pelaksanaan pengendalian serta kemasyarakatan. Pedoman umum juga mengkomodasi strategi dan inisiatif operasional lokal yang disesuaikan dengan keterbatasan dan keadaan masing-masing daerah. Pelaksanaan selanjutnya diatur dalam petunjuk sistem dan petunjuk pelaksanaan di tingkat provinsi di tingkat kabupaten/kota.

Kesalahan dalam pendistribusian rastra adalah bukan permaslahan baru bahkan masalah ini sudah lumrah terjadi dan banyak faktor seperti hal salah data atau keluarga yang mendapat jatah rastra yang sebelum masuk daftar sudah hidup berkecukupan dan sudah tidak layak lagi mendapat jatah rastra dari pemerintah tentu masalah ini sesungguhnya bisa diatasi dengan kerja sama antara pemerintah daerah dengan sering-sering melakukan monitoring ke rumah-rumah warga yang mendapat jatah untuk memastikan distribusi yang dilakukan pemerintah tepat sasaran karena masih banyak orang yang lebih membutuhkan juga belum mendapat jatah yang semestinya. Oleh karena, itu perlu dilakukan kerja sama yang baik antara pusat dan pemerintah daerah untuk menjalakannya.

Berdasarkan uraian di atas, maka peneliti tertarik untuk meneliti terkait "Pengaruh Budaya Organisasi terhadap Pengelolaan Rastra di Desa Bulucenrana Kecamatan Pitu Riawa Kabupaten Sidenreng Rappang" dengan tujuan Untuk mengetahui pengaruh budaya organisasi terhadap kinerja dalam pengelolaan Rastra di Desa Bulucenrana dan Untuk mengetahui faktorfaktor apa yang memengaruhi budaya organisasi di Desa Bulucenrana.

Budaya bersumber dari kata latin colere yang artinya menyuburkan, mengerjakan, mengolah, dan mengembangkan, terutama mengolah. Atau bisa juga didefinisikan sebagai aktivitas dan segala daya untuk mengubah dan mengolah alam. Budaya adalah kebiasaan dan nilai-nilai yang diterima sebagai contoh bersama yang dihormati dan diikutii. Menurut pandangan Jeff Cartwright 
Budaya adalah penetapkeyakinan yang kuat, perilaku dan sikap orang, dan pengaruhnya dapat diukur melalui bagaimana orang termotivasi untuk merespons pada lingkungan budaya mereka. Atas dasar itu Cartwright mendefenisikan budaya sebagai sebuah gabunganberbagai tujuan orang yang terorganisasi nilai-nilai dan dapat diukur dan dapat diukur dalam bentuk pengaruhnya pada motivasi(Khairani, 2018). Menurut Robbins dalam Sobirin, Achmad (2007:5), organisasi adalah unit kemasyarakatan untuk jangka waktu yang rcukup lama yang sengaja didirikan, beranggotakan dua orang atau lebih yang bekerja sama dan terkoordinasi, didirikan utnuk menyelesaiakn tujuan bersama mempunyai pola kerja tertentu yang terstruktur atau satu set tujuan yang telah ditentukan sebelumnya. Sedangkan menurut J. Bernard dalam Tika (2006:3) organisasi adalah kerj sama antara dua orang atau lebih, suatu kekuatan dari sistem perorangan yang dikoordinasikan secara sadar (Hakim Dalimunthe, 2019).

Robbins and Coulter (2010: 298) berpendapat bahwa budaya organisasi memiliki tujuh karateristik utama secara menyeluruh, yang adalah hakikat budaya sebuah organisasi, adalah:

1. Inovasi dengan keberanianmengambil resikoadalahsejauh mana organisasi mendorong para pegawai bersikap inovatif dan berani mengambil resiko, selain itu bagaimana organisasi menghargai tindakan pengambilan resiko oleh pegawai dan membangkitkan ide;

2. Perhatian terhadap detail atau perhatian pada hal-hal rinciadalah sejauh mana karyawandiharapkan menjalankan analisis, presisi, dan perhatian pada halhalrinci;

3. Orientasi buatanadalahsejauh mana mengatur lebih berfokus padabuatanketimbang pada proses dan teknik difungsikan dengan menyelesaiaknbuatan.

4. Orientasi orangadalahsejauh mana kesimpulan-kesimpulan mengatur mempertimbangkan efek daribuatan tersebut atas orang yang ada di organisasi;

5. Orientasi tim adalahsejauh mana aktivitas-aktivitas kerja diorganisasi pada tim ketimbang pada orang-orang;
6. Keagresifanadalahorang bersikap sejauh manabergairahdenganmasuk akalketimabng bebas;

7. Stabilitas adalahkegiatan organisasi sejauh mana status pada menekankan quodalam pertumbuhan dengan perbandingan;

Kata kinerjabersumberdari prestasi yang dicapai dengan sesungguhnya atau dengan kata job performance. Sehinggan kinerjapegawaiyaitubuatankerja seorang dari pencapaianpegawaidenganmenjalankan kewajiban dan tugas yang telah diberikan kinerja yaitu pencapaian buatanhasil kerja seorang pegawai dalam melaksanakan tugas sesuai dengan kemampuan yang dimiliki (Nur Yuliana, 2017). Menurut Mangkunegara (Alvi, 2012)mendefinisikan kinerja merupakanbuatankerja dengan cara kuantitas dan kualitas yang dicapai oleh seorangkaryawantugasnya dalam melaksanakan kerjanyan sesuai dengankewajibanyang diberikan kepadanya. Sedangkan menurut Wirawan, yaitu kinerja keluaran yang dibuatankan oleh manfaatmanfaat atau indikator-indikator suatu pekerjaan atau suatu profesi dalam waktu tertentu.

Winarni (dalam Masta, 2016) belaan beras miskin atau yang biasa disebut rastraadalah suatu belaan yang memberikan kepada keluarga miskin memberikan perlindungan melalui beras bersubsidifungsimewujudkan dengan mengurangi beban pengeluaran keluarga dn memenuhi kebutuhan gizi pada jumlah yang telah ditentukan. Perum Bulog (2010), program beras sejahtera merupakan perlindungan sosial dan satu program penanggulangan kemiskinan di bidang pangan yang diselengerakan kepada pemerintah pusat berbenukrumah tangga kepada belaan beras bersubsidimenurun.

Menurut buku panduan beras sejahtera (2014) dengan diperkuat seorang ahli menurut Sasongko (2009), menyatakan bahwa belaan rastra harus mengacu pada keenam indikator adalah, tepat sasaran penerima, tepat waktu, tepat harga tepat administrasi dan tepat kualitas. Alan tetapi menyusun dengan peneliti indikator belaan beras sejahtera hanya mengfungsikan tiga indikator (tepat harga, tepat jumlah, dan kecukupan beras sejahtera oleh keluarga yang menerima). Lebih jelasnya sebagai berikut: 
1. Tepat jumlah yang dimaksud tepat jumlah dalam hal ini merupkan jumlah belaan bansosadalah hak ketentuan yang berlaku sesuai hak RTS-PM, adalahRTS $/ 15 \mathrm{~kg}$ sebulan.

2. Tepat harga adapun yang dimaksud tepat harga dalam hal ini adalah harga yang ditebus pada titik pendistribusian sebesar Rp. 1.600/Kg.

3. Kecukupan beras sejahtera yang diterima kepada keluarga yang dimaksud adalahbelaan beras sejahterayang sudah didapatkan mecukupi pada hal beras yakni kebutuhan pangan dalam anggota setiap anggota keluarga.

Menurut pendapat Munandar (2010:264) budaya organisasi dipengaruhi oleh beberapa faktor adalah :

1. Faktor sejarah organisasi, dikendalikan kepada organisasi yang mencakup faktor yang tidak dapat dikendalikan sedikit.

2. Faktor budaya, kepercayaankepercayaan dan nilai-nilai yang dominan dari masyarakat luas misalnya kebersihan dan kesopan santunan.

3. Faktor bahasa, organisasi berinteraksi dengan lingkungannya dalam mengatasi baik masalah-masalah eksternal maupun internal, orang akan mendapatkan penyelesaian yang berbuatan.

\section{B. METODE PENELITIAN}

Jenis variabel dalam penelitian, yakni variabel independen (bebas) dan variabel dependen (terikat).Dalam penelitian ini, peneliti mengfungsikan dua variabel yakni budaya organisasi sebagai variabel independen (bebas) dan kinerja dalam pengelolaan rastrasebagai variabel dependen (terikat). Penelitian ini mengfungsikan tipe penelitian deskriptif kuantitatif, dengan metode ini diharapkan dapat memberikan gambaran secara cermat, jelas dan Objektif mengenai masalah yang sedang diteliti.

Populasi dalam penelitian ini adalah semua masyarakat yang tercatat sebagai anggota penerima rastra 2019 dengan jumlah 119 orang, Dusun I Bulucenrana 16 orang, Dusun II Pujo 24 orang, Dusun III Bottolita 53 orang, Dusun IV Bulecenrana 26 orang Jumlah populasi dalam penelitian ini adalah119 orang. Jumlah sampel yang digunakan yakni 54 sampel. Penarikan sampel dalam penelitian ini adalahpurpossive sampling atau definisi purpossive sampling.
Purpossive sampling merupakanteknik penentuan sampel dengan pertimbangan tertentu, yakni dengan pertimbangan usia 30 tahun ke atas dan yang pernah menerima rastra serra mengerti terkait budaya organisasi dan kinerja dalam pengelolaan rastra. Untk mendapatkan responden yang dijadikan sampel, satu hal penting yang harus diketahui oleh para peneliti adalah bahwa perlunya bagipengaranguntuk mengetahui jumlah responden yang ada dalam popilasi.

Tehnik Pengumpulan data yang digunakan adalah Observasi, Wawancara, Penelitian pustaka (library research), dan Kuesioner/Angket sedangkan tehnik analisis data yang digunakan yaitu statistik deskriptif dan dengan bantuan SPSS versi 21 untuk melakukan pengujian hipotesis. Hasil analisis berupa statistik deskriptif, uji kualitas (uji validitas validitas dan uji reliabilitas), analisis regresi linear sederhana dan uji hipotesis.

\section{HASIL DAN PEMBAHASAN}

Hasil penelitian Budaya Organisasi (X) : 1. Keberanian pegawai dalam mengambil resiko sebesar $64.4 \%$, 2. Pengelola pada halhal yang rinci sebesar $60.3 \%$, 3. Sejauhmana manajemen berfokus pada buatan ketimbang pada tekhnk dan proses sebesar $60 \%, 4$. Sejauhmana keputusan manajemen mempertimbangkan efek sebesar $65.4 \%, 5$. Kegiatan kerja di Organisasi pada tim ketimbang pada individu sebesar $53.6 \%, 6$. Pengelola bersifat agresif dan kompetitif ketimbang santai $55.4 \%$, dan 7 . Sejauhmana kegiatan organisasi menekankan pada pertumbuhan kinerja organisasi sebesar $58 \%$. Berdasarkan dari uraian tersebut, maka dapat disimpulkan bahwa Budaya Organisasi di Desa Bulucenrana berada pada Kategori Kurang Baik dengan Persentase 59.57\%.

Hasil penelitian Pengelolaan Rastra (Y) : 1. Jumlah belaan rastra sebesar $56.6 \%, 2$. Harga yang ditebus pada titik pendistribusian sebesar $56.2 \%$, dan 3. Apakah dari belaan rastra didapatkan sudah mencukupi kebutuhan pangan $54.4 \%$. Berdasarkan dari uraian tersebut, maka dapat disimpulkan bahwa Pengelolaan Rastra di Desa Bulucenrana berada pada Kategori Kurang Baik dengan Persentase $55.66 \%$.

Hasil penelitian Faktor-faktor yang memengaruhi Budaya Organisasi : 1. Faktor sejarah organisasi : kelangsungan hidup yang harus dihadapi oleh anggota organisasi 
$58 \%$, 2. Faktor budaya : apakah budaya organisasi telah mengikuti norma-norma yang berlaku di masyarakat $58,4 \%$ dan 3 . Faktor bahasa : masalah-masalah yang terjadi akan membentuk sebuah orgaisasi dalam suatu kelompok 54,4\%. Berdasarkan dari uraian tersebut, maka dapat disimpulkan bahwa Faktor-faktor yang memengaruhi Budaya Organisasi do Desa Bulucenrana berada pada Kategori Kurang Baik dengan Persentase $56.66 \%$.

Output ini menjelaskan tentang buatan uji validitas item. Berdasarkan dari output di atas untuk menguji tingkat validitas data yakni diketahui bahwa 7 item pertanyaan yang difungsikan untuk mengukur variabel Budaya Organisasi (X) dinyatakan valid dengan nilai corrected item-total correlation lebih besar dari $>0.25,0.30$ (corrected itemtotal correlation> $0.25,0.30)$. Output ini menjelaskan tentang buatan uji validitas item. Berdasarkan dari output di atas untuk menguji tingkat validitas data yakni diketahui bahwa 3 item pertanyaan yang difungsikan untuk mengukur variabel Kinerja dalam Pengelolaan Rastra dinyatakan valid dengan nilai corrected item-total correlation lebih besar dari $>0.25,0.30$ (corrected item-total correlation> 0.25, 0.30). Output ini menjelaskan tentang buatan uji validitas item. Berdasarkan dari output di atas untuk menguji tingkat validitas data yakni diketahui bahwa 3 item pertanyaan yang difungsikan untuk mengukur Faktor-faktor yang memengaruhi Budaya Organisasi dinyatakan valid dengan nilai corrected item-total correlation lebih besar dari $>0.25,0.30$ (corrected item-total correlation> 0.25, 0.30).

Uji reliabilitas adalah alat untuk mengukur konsistensi suatu kuesioner yang adalah indikator dari variabel atau konstruk.Suatu kuesioner dikatakan reliable atau handal jika jawaban seseorang terhadap pertanyaan adalah konsisten atau stabil dari waktu ke waktu.Suatu konstruk atau variabel dikatakan reliable jika memberikan nilai cronbach Alpha $>0.60$. Output tersebut sebagai buatan dari analisis reliabilitas cronbach alpha.Berdasarkan output tabel reliability statisticsdi atas, kuesioner penelitian yang difungsikan untuk mengukur variabel Budaya Organisasi (X) reliabel karena Cronbach Alphayang diperoleh adalah sebesar 0.764 yang berarti lebih besar dari $0.60(0.714>0.60)$.
Output tersebut sebagai buatan dari analisis reliabilitas cronbach alpha. Output tersebut sebagai buatan dari analisis reliabilitas cronbach alpha. Berdasarkan output tabel reliability statisticsdi atas, kuesioner penelitian yang difungsikan untuk mengukur variabel Kinerja dalam Pengelolaan Rastra (Y) reliabel karena Cronbach Alphayang diperoleh adalah sebesar 0.674 yang berarti lebih besar dari $0.60(0.674>0.60)$.

Output tersebut sebagai buatan dari analisis reliabilitas cronbach alpha. Output tersebut sebagai buatan dari analisis reliabilitas cronbach alpha.Berdasarkan output tabel reliability statisticsdi atas, kuesioner penelitian yang difungsikan untuk mengukur Fakto-faktor yang memengaruhi Budaya Organisasi reliabel karena Cronbach Alphayang diperoleh adalah sebesar 0.603 yang berarti lebih besar dari $0.60(0.603>$ 0.60). Output di atas diketahui bahwa grafik normal P-P Plot buatan olah data, maka model regres dalam penelitian ini memenuhi anggapan normalitas yakni data menyebar di sekitar garis diagonal dan mengikuti arah garis diagonal, atau grafik histogramnya menunjukkan pola distribusi normal, maka resgresi memenuhi anggapan normalitas.

Output di atas diketahui bahwa variabel independen yang dimasukkan ke dalam model adalah Budaya Organisasi dan variabel dependennya adalah Pengelolaan Rastra.Sedangkan metode regresi yang difungsikan adalah Enter. Output di atas menjelaskan bahwa dari tabel Model Summary, pada bagian ini ditampilkan ni $\mathrm{R}=$ 0.756 dan koefisien Determination Rsquare atau $\left(R^{2}\right)$ nilai sebesar 0.571 (buatan dari pengkuadratan koefisienkorelasi atau (R) $0.756 \times 0.756=0.571 \times 100 \%=57.1 \%)$, sedangkan sisanya $(100 \%-57.1 \%=42.9$ $\%)$. Hal ini menunjukkan bahwa untuk mencari besar faktor Budaya Organisasi (X) terhadap Kinerja dalam Pengelolaan Rastra (Y) dengan ini nilai yang dicari adalah $57,1 \%$.

Buatan dari uji ANOVApada bagian ini ditampilkan buatan yang diperoleh adalah nilai $F=7.562$ dengan tingkat probabilitas sig. 0.008. Oleh karena probabilitas $(0,008)$ jauh lebih kecil dari 0.05 , maka model regresi bisa dipakai untuk memprediksi Budaya Organisasi. Untuk menguji kebenaran hipotesis dalam penelitian ini dilakukan uji $\mathrm{F}$. Untuk mengetahui bahwa pengaruh/Signifikan dapat diketahui dengan 
melihat dari lefel of signifikan $a=0,05$. Jika nilai signifikan lebih kecil dari 0,05 , maka $\mathrm{HO}$ ditolak dan Ha diterima. Berdasarkan buatan olah pada tabel ANOVA, maka diketahui nilai Fhitung yang diperoleh sebesar 7.562dengan tingkat signifikan 0,008 (Sig < 0,05) yang berarti bahwa variabel Budaya Organisasi $(X)$ mempunyai pengaruh/signifikan terhadap Kinerja dalam Pengelolaan Rastra $(Y)$, dari buatan tersebut berarti model regresi dapat difungsikan untuk memprediksi Kinerja dalam Pengelolaan Rastra di Desa Bulucenrana Kecamatan Pitu Riawa Kabupaten Sidenreng Rappang.

Berdasarkan tabel Coefficientsbuatan olah data, maka model regresi yang difungsikan dalam penelitian ini untuk mengukur pengaruh Budaya Organisasi terhadap Kinerja dalam Pengelolaan Rastra di Desa Bulucenrana Kecamatan Pitu Riawa Kabupaten Sidenreng Rappang.

$Y=4.776+1.395 X$

Dari manfaat regresi di atas, maka dapat dijelaskan :

1. Jika variabel Budaya Organisasi (X) berubah, maka Kinerja dalam Pengelolaan Rastra ( $Y$ ) juga akan berubah. Tanda positif menunjukkan perubahan yang searah. Apabila Budaya Organisasi meningkat, maka Kinerja dalam Pengelolaan Rastra juga akan meningkat dengan koefisien regresi sebesar 1.395 dan sebaliknya, jika Budaya Organisasi menurun, maka Kinerja dalam Pengelolaan Rastra juga akan menurun dengan koefisien regresi sebesar 1.395

2. Nilai konstanta sebesar 4.776 menunjukkan bahwa, jika semua variabel konstan maka Budaya Organisasi masih bersifat positif.

Uji statistic $t$ untuk menunjukkan seberapa jauh pengaruh satu variabel penjelas/independen secara individual menerangkan variasi variabel dependen berdasarkan tabel coefficients buatan olah data SPSS, maka diketahui bahwa :

a. Nilai thitungvariabel Budaya Organisasi (X) 2.750 dengan tingkat signifikan 0,001.

b. Hipotesis berdasarkan uji t dirumuskan secara statistic

$\mathrm{Ha}:$ Pyx $\neq 0$

$\mathrm{HO}:$ Pyx $\neq 0$

Hipotesis bentuk kalimat:

1. $\mathrm{Ha}$ :Budaya Organisasi berpengaruh/signifikan terhadap Kinerja dalam Pengelolaan Rastra di Desa Bulucenrana Kecamatan Pitu Riawa Kabupaten Sidenreng Rappang.

2. HO : Kompetensi Sumber Daya Manusia tidak berpengaruh/signifikan terhadap Kinerja dalam Pengelolaan Rastra di Desa Bulucenrana Kecamatan Pitu Riawa Kabupaten Sidenreng Rappang

Pengambilan Keputusan :

1. Jika nilai $t$ hitung $\geq t$ tabel, maka $\mathrm{HO}$ ditolak dan Ha diterima, artinya Signifikan

2. Jika nilai $\mathrm{t}$ hitung $\leq \mathrm{t}$ tabel, maka $\mathrm{HO}$ diterima dan $\mathrm{Ha}$ ditolak, artinya tidak Signifikan.

Tabel Coefficients diperoleh $\mathrm{t}$ hitung $=$ 2.750 prosedur mencari statistic tabel dengan kriteria

1. Tingkat signifikan $(a=0,05)$

2. $\mathrm{df}=$ Jumlah Responden -2 atau 54 $-2=52$

3. ttabel $=a / 2 ; d f$

$$
=0,05 / 2 ; \mathrm{df}
$$$$
=0,025 ; 52
$$

Sehingga $\mathrm{t}$ tabel $=2,006$

Keputusan :

Ternyata nilai $\mathrm{t}$ hitung $>\mathrm{t}$ tabel atau $2.750>2.006$, maka $\mathrm{HO}$ ditolak dan $\mathrm{Ha}$ diterima, artinya signifikan. Jadi, Budaya Organisasi berpengaruh signifikan terhadap Kinerja dalam Pengelolaan Rastra di Desa Bulucenrana Kecamatan Pitu Riawa Kabupaten Sidenreng Rappang.

Berdasarkan pada keputusan yang telah dipaparkan tentang pengujian hipotesis dapat dijelaskan bahwa Ho ditolak dan $\mathrm{Ha}$ diterima dengan kata lain $\mathrm{t}$ hitung $>\mathrm{t}$ tabel $(2.750>2.006)$ artinya Signifikan. Dari data tersebut dapat dikatakan bahwa Budaya Organisasi berpengaruh signifikan terhadap Kinerja dalam Pengelolaan Rastra di Desa Bulucenrana Kecamatan Pitu Riawa Kabupaten Sidenreng Rappang. Jika Budaya Organisasi yang dimiliki belum memberikan sumbangsih yang optimal maka akan mengurangi tingkat keberbuatanan dalam pelaksanaan tugas-tugasnya terutama pada hal kinerja dalam pengelolaan rastra yang berkualitas. Halini sesuai dengan yang dikemukakan oleh Robbins and Coulter (2010: 298) berpendapat bahwa budaya organisasi adalah Inovasi dan keberanian mengambil resiko, Perhatian pada hal-hal rinci atau perhatian terhadap detail, dan untuk menyelesaiakn kesuksesan pekerjaannya terutama pada kinerja dalam 
pengelolaan rastra. Semakin baik budaya organisasi kompetensi makasemakin baikkualitas tatakelola pemerintahdesahal tersebut akanmeningkatkan kualitas pelayanan terutama kinerja dalam pengelolaan rastraserta meningkatkan kepercayaan masyarakat terhadap kinerja pemerintah desa dalam memnberikan pengelolaan yang berkualitas.

Berdasarkan data distribusi frekuensi variabel budaya organisasi dapat dilihat bahwa tingkat capaian responden sebesar $59,57 \%$. Ini memperlihatkan bahwa nilai tingkat capaian responden berada pada kategori kurang baik maka dari itu budaya organisasi harus tetap ditingkatkan, utamanyalnovasi dan keberanian mengambil resiko, Perhatian pada hal-hal rinci atau perhatian terhadap detail, Orientasi buatan, Orientasi orang, Orientasi tim, Keagresifan, dan Stabilitasagar dapat mengoptimalkan dan memaksimalkan kemampuan, kualitas serta pengetahuan individupada hal kinerja dalam pengelolaan rastra. Sedangkan data disritbusi frekuensi variable kinerja dalampengelolaan rastra dapat dilihat bahwa tingkat capaian responden yang diberikan adalah $55,66 \%$ yang terdiri dari 3 indikator kinerja dalam pengelolaan rastra yang dikemukakan oleh Kinerja dalam Pengelolaan Rastra Sasongko (2009) yakni Tepat jumlah, Tepat harga dan Kecukupan rastra.

Berdasarkan buatan analisis data tersebut diperoleh capaian responden sebesar $55,66 \%$ berada pada kategori kurang baik dikarenakan penerapan budaya organisasi yang dimiliki aparat dalam hal pemberian layanan yakni pada hal kinerja dalam pengelolaan rastra masih dinilai belum memberikan sumbangsih yang optimal dalam pelaksanaan tugas-tugasnya terutama pada hal kinerja dalam pengelolaan yang berkualitas danbuatan penelitian ini sejalan dengan penelitian penelitian sebelumnya yang dilakukan oleh Wambugu (2014) yang melakukan penelitian tentang Pengaruh Budaya Organisasi terhadap Pengeolaan Rastra pada Desa Bulucenrana Kecamatan Pitu Riawa. Buatan dari penelitian ini mengungkapkan bahwa nilai-nilai organisasi memiliki efek yang lebih signifikan terhadap prestasi kerja dan kinerja dalam pengelolaan rastra di Desa Bulucenrana. Pada penelitian ini juga dikatakan bahwa adanya pengaruh positif antara budaya organisasi dan kinerja dalam pengelolaan rastra dilihat dari proses dan sistem kerja yang berpengaruh terhadap kinerja dalam pengelolaan rasrta.

Data distribusi frekuensi faktor-faktor yang memengaruhi budaya organisasi dapat dilihat bahwa tingkat capaian responden sebesar $56,66 \%$ ini memperlihatkan capaian responden yang diberikan berada pada kategori kurang baik ini dikarenakan minimnya antusias pemerintah desa dalam peningkatan budya dalam organisasi tersebut. Sesuai yang dikemukakan oleh Munandar (2010:264) yang mengatakan bahwa keyakinan-keyakinan dan nilai-nilai yang dominan dari masyarakat luas misalnya kesopan santunan dan kebersihan serta organisasi selalu berinteraksi dengan lingkungannya dalam mengatasi baik masalah-masalah eksternal maupun internal, orang akan mendapatkan penyelesaian yang berbuatan.

\section{KESIMPULAN}

1. Berdasarkan dari analisis data bahwa Pengaruh Budaya Organisasi terhadap Pengelolaan Rastra di Desa Bulucenrana Kecamatan Pitu Riawa Kabupaten Sidenreng Rapanng dapat dikatakan berpengaruh dan signifikan. Berdasarkan buatan perhitungan SPSS versi 21 maka, t hitung $>$ t tabel $2.750>2.006$ maka $\mathrm{HO}$ ditolak dan Ha diterima, artinya signifikan dengan kategori kurang baik dengan melihat buatan ideal presentase $57.1 \%$.

2. Buatan penelitian Faktor-faktor yang Memengaruhi Budaya Organisasi: 1. Faktor sejarah organisasi : kelangsungan hidup yang harus dihadapi oleh anggota organisasi $58 \%$, 2. Faktor budaya : apakah budaya organisasi telah mengikuti norma-norma yang berlaku di masyarakat $58,4 \%$ dan 3 . Faktor bahasa : masalah-masalah yang terjadi akan membentuk sebuah orgaisasi dalam suatu kelompok $54,4 \%$.

\section{E. REFERENSI Buku}

Ahmad, Jamaluddin. 2015. Metode Penelitian Tata laksana Publik Teori dan Aplikasi. Gava Media. Yogyakarta.

\section{Jurnal}

Dwi Marta, J., \& Triwijayanti, D. (2018). Pengaruh Budaya Organisasi dan Komunikasi Organisasi terhadap Kinerja 
Pegawai PT. X. BISMA (Bisnis Dan Manajemen), 8(2), 218,

Fauzan, H. S. (2017). Filsafat ilmu tata laksana sebagai hakikat dan makna dalam keilmuan tata laksana publik. Jurnal Pembanfungsin Dan Kebijakan Publik, 8(1), 31-42.

Febrian, R. (2017). Pengaruh Budaya Otganisasi terhadap Kinerja Pegawai dengan Loyalitas sebagai Variabel Moderasi pada PT Astra Internasional TBK. Auto 2000 Cabang Raden Intan Bandar Lampung. 1-14.

Hakim Dalimunthe, A. (2019). Pengaruh Budaya Organisasi dan Iklim Organisasi terhadap Kinerja Pegawai. Jurnal Dimensi, 7(2).

Ramadhany Putra, D. (2018). Pengaruh Belaan Raskin terhadap Kelangsungan Hidup Masyarakat Kurang Mampu (Studi pada Status Kemasyarakatan Ekonomi Masyarakat Kelurahan Tanjung Agung Raya, Kecamatan Kedamaian, Kota Bandar Lampung).

Adi, I. (2017). Analisis Pengaruh Budaya Organisasi dan Komunikasi Organisasi terhadap Kinerja Pegawai dengan Komitmen Organisasi sebagai Variabel Intervening ( Studi Kasus PT. Bank BTN KCS Yogyakarta ) SKRIPSI Diajukan.

Khairani, R. (2018). Pengaruh Budaya Organisasi dan Motivasi Kerja terhadap Kinerja Tenaga Kependidikan di SMP Swasta Darussalam Medan. (2).

Maslukhan, F. (2019). Pengaruh Budaya Organisasi Dan Komitmen Organisasi Terhadap Kinerja Pegawai. Jurnal Riset Manajemen Dan Bisnis (JRMB) Fakultas Ekonomi UNIAT, 4(1), 119-126.

Alvi. (2012). Pengaruh Budaya Organisasi dan Iklim Organisasi Terhadap Kinerja Tenaga Paramedis Rumah Sakit Jiwa Tampan pekanbaru. 